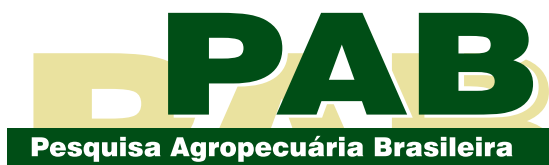

ISSN 1678-3921

Journal homepage: www.embrapa.br/pab For manuscript submission and journal contents, access: www.scielo.br/pab

Rita de Cássia Alves(1) (iD, José Roberto Vieira Júnior ${ }^{(2)}$ (iD, Tamiris Chaves Freire ${ }^{(1)}$ (D), Aline Souza da Fonseca ${ }^{(1)}$ (iD), Simone Carvalho Sangi(1) (D), Fábio da Silva Barbieri( ${ }^{(3)}$ (D), Rodrigo Barros Rocha ${ }^{(4)}$ (iD, Luciana Gatto Brito(3) (iD, Soraya dos Santos Pereira(5) (iD, Marcos Barros Luiz ${ }^{(6)}$ (iD, Francisco das Chagas Oliveira Freire ${ }^{(2)}$, Carla Freire Celedonio Fernandes ${ }^{(7)}($ D), Andreimar Martins Soares ${ }^{(5)}$ (iD) and Cléberson de Freitas Fernandes ${ }^{(2 \otimes)}$ (iD)

(1) Universidade Federal de Rondônia, Programa de Pós-Graduação em Ciências Ambientais, Avenida Norte Sul, no 7.300, Nova Morada, CEP 76940-000 Rolim de Moura, RO, Brazil. E-mail: rita_diggory@hotmail.com, tamirischavesfreire@ rita_diggory@hotmail.com, tamirischavesfreire@ simonecarvalhosangi@gmail.com

(2) Embrapa Agroindústria Tropical, Rua Dra. Sara Mesquita, oㅡ 2.270, Planalto do Pici, CEP 60511110 Fortaleza, CE, Brazil. E-mail: jose-roberto. vieira@embrapa.br, francisco.o.freire@embrapa.br cleberson.fernandes@embrapa.br

(3) Embrapa Amazônia Oriental, Travessa Dr. Enéas Pinheiro, s/no, Marco, Caixa Postal 48 CEP 66095-903 Belém, PA, Brazil. E-mail: fabio. barbieri@embrapa.br, luciana.gatto@embrapa.br

(4) Embrapa Rondônia, BR-364, Km 5,5, s/no CEP 76815-800 Porto Velho, RO, Brazil. E-mail: rodrigo.rocha@embrapa.br

(5) Fundação Oswaldo Cruz - Rondônia, Rua da Beira, no 7.671, BR 364, Km 3,5, Lagoa, CEP 76812-245 Porto Velho, RO, Brazil. E-mail: soraya.santos@fiocruz.br, andreimar.soares@fiocruz.br

(6) Instituto Federal de Educação, Ciência e Tecnologia de Rondônia, Avenida 15 de Novembro, № 4849, Planalto, CEP 76850-000 Guajará-Mirim, RO, Brazil. E-mail:marcos.barros@ifro.edu.br

(7) Fundação Oswaldo Cruz - Ceará, Avenida São José, s/no, Precabura, CEP 61760-000 Eusébio, CE, Brazil. E-mail: carla.celedonio@fiocruz.br

$\bowtie$ Corresponding author

Received

December 30, 2019

Accepted

September 24, 2020

How to cite

ALVES, R. de C.; VIEIRA JÚNIOR, J.R.; FREIRE, T.C. FONSECA, A.S. da; SANGI, S.C.; BARBIERI, F. da S.; ROCHA, R.B.; BRITO, L.G.; PEREIRA, S. dos S.; LUIZ, M.B.; FREIRE, F. das C.O.; FERNANDES, C.F.C. SOARES, A.M.; FERNANDES, C. de F. Snake venoms and purified toxins as biotechnological tools to control Ralstonia solanacearum. Pesquisa Agropecuária Brasileira, v55, 01756, 2020. DOI: https//1doi. org/10.1590/S1678-3921.pab2020.v55.01756.
Phytopathology/ Original Article

\section{Snake venoms and purified toxins as biotechnological tools to control Ralstonia solanacearum}

\begin{abstract}
The objective of this work was to evaluate the in vitro antibacterial activity of snake venoms and purified toxins on the phytopathogenic bacterium Ralstonia solanacearum. The evaluations were performed with 17 crude venoms (13 from Bothrops, 3 from Crotalus, and 1 from Lachesis) and seven toxins (1 from Bothrops and 6 from Crotalus). Antibacterial activity was assessed in MB1 medium containing solubilized treatments $\left(1 \mu \mathrm{L} \mathrm{mL}^{-1}\right)$. A total of $100 \mu \mathrm{L}$ bacterial suspension $\left(8.4 \times 10^{9} \mathrm{CFU} \mathrm{mL}^{-1}\right)$ was used. After incubation at $28^{\circ} \mathrm{C}$, the number of bacterial colonies at 24,48 , and 72 hours after inoculation was evaluated. SDS-PAGE gel at $15 \%$ was used to analyze the protein patterns of the samples, using $5 \mu \mathrm{g}$ protein of each sample in the assay. Furthermore, the minimum inhibitory concentration (MIC) and lethal concentration $\left(\mathrm{LC}_{50}\right)$ values were determined by the Probit method. Venoms and toxins were able to reduce more than $90 \%$ of $R$. solanacearum growth. These results were either equivalent to those of the positive control chloramphenicol or even better. While MIC values ranged from 4.0 to $271.5 \mu \mathrm{g} \mathrm{mL}^{-1}, \mathrm{LC}_{50}$ ranged from $28.5 \mu \mathrm{g} \mathrm{mL}{ }^{-1}$ to $4.38 \mathrm{mg} \mathrm{mL}^{-1}$. Ten crude venoms (7 from Bothrops and 3 from Crotalus) and two purified toxins (gyroxin and crotamine) are promising approaches to control the phytopathogenic bacterium $R$. solanacearum.
\end{abstract}

Index terms: Bothrops, Crotalus, antimicrobial activity, bacterial wilt, crotamine, gyroxin.

\section{Venenos e toxinas ofídicas purificadas como ferramenta biotecnológica para o controle de Ralstonia solanacearum}

Resumo - O objetivo deste trabalho foi avaliar a atividade antibacteriana in vitro de venenos e toxinas purificadas de serpentes sobre a bactéria fitopatogênica Ralstonia solanacearum. As avaliações foram realizadas em 17 venenos brutos (13 de Bothrops, 3 de Crotalus e 1 de Lachesis) e sete toxinas (1 de Bothrops e 6 de Crotalus). A atividade antibacteriana foi avaliada em meio MB1 que continha os tratamentos solubilizados $(1 \mu \mathrm{L} \mathrm{mL}-1)$. Utilizou-se o total de $100 \mu \mathrm{L}$ de suspensão bacteriana $\left(8,4 \times 10^{9} \mathrm{UFC} \mathrm{mL}^{-1}\right)$. Após incubação a $28^{\circ} \mathrm{C}$, avaliou-se o número de colônias bacterianas às 24,48 e 72 horas após a inoculação. O gel SDS-PAGE a 15\% foi usado para analisar o perfil proteico das amostras, tendo-se utilizado $5 \mu \mathrm{g}$ de proteína no ensaio. Além disso, os valores de concentração inibitória mínima (CIM) e concentração letal $\left(\mathrm{CL}_{50}\right)$ foram determinados pelo método Probit. Os venenos e as toxinas foram capazes de reduzir mais de $90 \%$ do crescimento de $R$. solanacearum. Esses resultados foram ou equivalentes aos do controle positivo cloranfenicol ou até melhores. Enquanto os valores de CIM variaram de 4,0 a $271,5 \mu \mathrm{g} \mathrm{mL}^{-1}$, a $\mathrm{CL}_{50}$ variou de $28,5 \mu \mathrm{g} \mathrm{mL}^{-1}$ a $4,38 \mathrm{mg} \mathrm{mL}^{-1}$. Dez venenos brutos (7 de Bothrops e 3 de Crotalus) e duas toxinas (giroxina e crotamina) são abordagens promissoras para o controle da bactéria fitopatogênica $R$. solanacearum.

Termos para indexação: Bothrops, Crotalus, atividade antimicrobiana, murcha bacteriana, crotamina, giroxina. 


\section{Introduction}

Through large-scale production systems, conventional agriculture plays an important role to attend to the growing food demand. However, food production can be affected by several factors, including pathogen attacks on host plants. Overall, it is estimated that, for many crops, potential loss caused by pathogens can reach over $30 \%$ of agricultural production worldwide (Yuliar et al., 2015; Rodrigues et al., 2020).

Phytobacteria can cause damage to several crops of economic interest and are responsible for important losses globally. Ralstonia solanacearum, one of the most important plant pathogenic bacterium, is responsible for important diseases in different crops, such as bacterial wilt, brown rot, and Moko disease in potato, tomato, and banana (Baptista et al., 2007; Peeters et al., 2013). In some cases, even with management measures, crop production may be seriously affected by $R$. solanacearum infection. The pathogen induces rapid and destructive damage to host tissues. This bacterium is a soil-borne pathogen with a large host variety, it penetrates the plants through their roots, reaching the xylem vessels where its multiplication occurs (Yadeta \& Thomma, 2013; Dalsing et al., 2015).

Chemical products have been used for disease control, but, despite their efficiency, they are highly expensive and can cause damage to the environment and human health (Kwak et al., 2015). Thus, innovative products able to effectively control crop diseases with minimal impact on environmental and human populations are needed. In this scenario, natural/ synthetic antimicrobial molecules, as well as animal and vegetal biodiversity emerge as an immeasurable source of compounds with potential to control $R$. solanacearum strains. Some studies have shown that the essential oil extracted from Lantana camara and epsilon-poly-L-lysine (EPL), an antimicrobial peptide (AMP), inhibited bacteria growth (Cespedes et al., 2015; Mohamed et al., 2019; Rodrigues et al., 2020). These results can provide new antimicrobial substances, which are extremely important due to the current widespread of bacterial resistance (Datta et al., 2015).

Snake venoms are a rich source of molecules with active pharmacological properties, including antimicrobial activity, many new, biologically active peptides from them have been discovered (Toyama et al., 2006; Tashima et al., 2012; Samy et al., 2016; Almeida et al., 2017; Boldrini-França et al., 2017; Resende et al., 2017). An L-amino acid oxidase (LAAO) isolated from Bothrops arajoensis crude venom inhibited Pseudomonas aeruginosa, Candida albicans, and Staphylococcus aureus growth and showed parasitic activity against Leishmania spp. (Torres et al., 2010). Another LAAO, isolated from $B$. atrox crude venom, showed anti-protozoal activities against Trypanosoma cruzi and Leishmania spp. (Paiva et al., 2011). Furthermore, a lectin isolated from $B$. leucurus crude venom showed antibacterial activity against $S$. aureus, Enterococcus faecalis, and Bacillus subtilis (Nunes et al., 2011).

Because of the relevance of $R$. solanacearum and its impact on crop production, new solutions have been searched for the improvement of crop productivity, cost and toxicity of chemical products, growing number of antibiotic-resistant bacteria, as well as results showing antibacterial effects of snake venom compounds, and new biotechnological tools to control plant diseases.

The objective of this work was to evaluate the in vitro antibacterial activity of snake venoms and purified toxins on the phytopathogenic bacterium $R$. solanacearum.

\section{Materials and Methods}

Crude venoms and purified toxins were acquired from Serpentário de Proteínas Bioativas Ltda. (Batatais, SP, Brazil) and also obtained from the Centro de Estudos de Biomoléculas Aplicadas à Saúde (CEBio) (Fundação Oswaldo Cruz, Rondônia state, Brazil). Licenses were obtained from Instituto Brasileiro do Meio Ambiente (Ibama, license number 27131-2), and Conselho de Gestão do Patrimônio Genético (CGEN, no. 010627/2011-1). Venoms used from Bothrops spp., Crotalus spp., and Lachesis muta are presented in Table 1. The toxin BthTX-I was isolated from B. jararacussu snake venom (Andrião-Escarso et al., 2000). Isolated toxins (Bercovici et al., 1987) from Crotalus durissus terrificus venom (convulxin, gyroxin, crotamine, crotoxin, PLA2-CB, and CAcrotapotin) were kindly provided by Prof. Dr. J.R. Giglio (in memoriam), from Faculdade de Medicina de Ribeirão Preto, Universidade de São Paulo (FMRPUSP), Ribeirão Preto, SP, Brazil.

The protein profiles of the venoms and purified toxins were evaluated electrophoretically under 
reducing conditions using $15 \%$ polyacrylamide gels containing sodium dodecyl sulfate (SDS-PAGE) (Laemmli, 1970). For the analyses, total protein concentration was determined using bicinchoninic acid (BCA) method (Smith et al., 1985), and final concentration was adjusted to $5 \mu \mathrm{g}$ for each sample in $20 \mu \mathrm{L}$ final volume.

An electrophoretic run was carried out $(100 \mathrm{~V}$, $180 \mathrm{~min}$ ), and gels were stained with $0.5 \%$ G-250 Coomassie Blue solution. Amersham ECL Rainbow Marker - Full Range kit (GE Healthcare, Amersham, Buckinghamshire, UK) was used as a molecular weight marker.

The bioactive potential of venoms and toxins was evaluated against the phytopathogenic bacterium Ralstonia solanacearum after solubilizing venoms and toxins in phosphate-buffered saline (PBS), $\mathrm{pH} 7.4$, to 2 $\mathrm{mg} \mathrm{mL} \mathrm{m}^{-1}$ final concentration.

Bacterial cultures were grown in liquid MB1 medium (medium 523) (Kado \& Heskett, 1970) for 12 hours under agitation $\left(100 \mathrm{rpm}, 28^{\circ} \mathrm{C}\right)$. Bacterial growth was monitored using a spectrophotometer until it reached approximately 0.5 for $\mathrm{A}_{540}$. For serial dilution preparations, $1 \mathrm{~mL}$ of each bacterial suspension was added to $9 \mathrm{~mL}$ of sterile mineral water. After homogenization, $1 \mathrm{~mL}$ was transferred from tube 1 to tube 2 that contained $9 \mathrm{~mL}$ of sterile mineral water. This procedure was repeated through tube 10 .

Table 1. Identification of snake species, venoms and toxins used in the antibacterial assays against Ralstonia solanacearum.

\begin{tabular}{lccc}
\hline Snake species & Sample $^{(1)}$ & Snake species & Sample $^{(1)}$ \\
\hline Bothrops & $\mathrm{V}$ & B. neuwiedi & $\mathrm{V}$ \\
BthTX-I & $\mathrm{T}$ & B. pauloensis & $\mathrm{V}$ \\
B.jararaca & $\mathrm{V}$ & Crotalus durissus terrificus & $\mathrm{V}$ \\
B. diporus & $\mathrm{V}$ & Gyroxin & $\mathrm{T}$ \\
B. marajoensis & $\mathrm{V}$ & Crotamine & $\mathrm{T}$ \\
B. alternatus & $\mathrm{V}$ & Crotapotin & $\mathrm{T}$ \\
B.urutu & $\mathrm{V}$ & Crotoxin & $\mathrm{T}$ \\
B. atrox & $\mathrm{V}$ & Convulxin & $\mathrm{T}$ \\
B. insularis & $\mathrm{V}$ & PLA2-CB & $\mathrm{T}$ \\
B. leucurus & $\mathrm{V}$ & C. durissus cascavella & $\mathrm{T}$ \\
B. brazili & $\mathrm{V}$ & C. atrox & $\mathrm{V}$ \\
B. moojeni & $\mathrm{V}$ & Lachesis muta & $\mathrm{V}$ \\
\hline
\end{tabular}

(1) $\mathrm{V}$, venom; $\mathrm{T}$, toxin.
Petri dishes $(80 \mathrm{~mm}$ diameter $)$ containing solid MB1 medium were prepared, and $100 \mu \mathrm{L}$ of each bacterial suspension dilution were deposited onto each plate. Plates were incubated at $28^{\circ} \mathrm{C}$ for 24 hours in a bacteriological oven, while serial dilutions were stored at $4^{\circ} \mathrm{C}$. Subsequently, the number of colony forming units ( $\mathrm{CFU} \mathrm{mL} \mathrm{m}^{-1}$ ) was determined using the formula: $\mathrm{CFU}=\mathrm{NC} \times 10^{\text {tube }} /$ aliquot $(\mathrm{mL})$, in which $\mathrm{NC}$ is the number of colonies, and $10^{\text {tube }}$ is the selected dilution tube used in the assay. Each plate containing 30-300 colonies was selected, and the respective dilution tube was used for antibacterial assay (adapted from Kass, 1956).

Hereafter, the plates for preliminary screenings were prepared with semi-solid MB1 medium containing the solubilized treatments $(1 \mu \mathrm{L}$ of venom or toxin per $\mathrm{mL}$ of culture medium). Samples were added to MB1 medium after autoclaving and when agar cooled down to $40^{\circ} \mathrm{C}$. After solidification, $100 \mu \mathrm{L}$ of the selected bacterial dilution tube $\left(8.4 \times 10^{9} \mathrm{CFU} \mathrm{mL}^{-1}\right)$ were deposited and scattered using Drigalski's spatula. The plates were incubated in a bacteriological oven at $28^{\circ} \mathrm{C}$, and the number of bacterial colonies were evaluated at 24, 48, and 72 hours after inoculation. Chloramphenicol $\left(0.5 \mathrm{mg} \mathrm{mL}^{-1}\right)$ and PBS were used as positive and negative controls, respectively. All treatments were carried out in triplicate.

To determine the minimum inhibitory concentration (MIC) and lethal concentration $\left(\mathrm{LC}_{50}\right)$ values, venoms and toxins were solubilized in PBS pH 7.4, with a final concentration of $2 \mathrm{mg} \mathrm{mL}^{-1}$ and $0.6 \mathrm{mg} \mathrm{mL}^{-1}$ for venoms and toxins, respectively. MIC test was carried out only when effective results were evident, as observed across the treatments. Graphical representation of sample concentrations in relation to the inhibition percentage allowed of the $\mathrm{LC}_{50}$ determination by Probit analysis.

MIC was determined using Probit analysis to evaluate the percentage of bacterial colonies that did not survive in the applied concentrations of venoms and toxins. Seven different venom concentrations (31.25 $\left.\mu \mathrm{g} \mathrm{mL}^{-1}-2 \mathrm{mg} \mathrm{mL}^{-1}\right)$ and toxins $(9.37 \mu \mathrm{g}$ $\mathrm{mL}^{-1}-0.6 \mathrm{mg} \mathrm{mL}^{-1}$ ) were prepared and used in the analyses. Chloramphenicol and PBS were also evaluated as positive and negative controls, respectively. Antibacterial assays were carried out as previously described. As a means of standardizing the evaluations, all dilutions were performed immediately prior to assembling the experiments. In the evaluation 
of antibacterial activity, the $\mathrm{LC}_{50}$ value corresponds to the concentration responsible for the inhibition of $50 \%$ of the number of colonies, and the MIC is considered to be the concentration that inhibits $1 \%$ of bacterial growth.

For the screening tests, a completely randomized design was considered in a factorial arrangement with three replicates, to test 24 single concentration treatments and two controls(PBS and chloramphenicol). Data were subjected to the analysis of variance, and the means were compared using the Tukey's test, at $1 \%$ probability. Statistical analyses were performed using the Genes software (Cruz, 2016).

\section{Results and discussion}

The evaluated protein patterns of venoms showed that the presence of proteins ranged mainly between 12 and $76 \mathrm{kDa}$ (Figure $1 \mathrm{~A}$ and B), while most of the isolated toxins had a molecular weight smaller than $20 \mathrm{kDa}$ (Figure 1 C). These protein patterns are similar to those of others snake venoms, as well as compounds isolated from them (Torres et al., 2010; Nunes et al., 2011).

The antibacterial activity assays of snake venoms and toxins against colonies of $R$. solanacearum were subjected to analysis of variance and a significant reduction in colonies was observed (Table 2). Out of the 24 venoms and toxins evaluated in the present study, 12 showed antibacterial activity against $R$. solanacearum (Figure 2). Seven Bothrops venoms ( $B$. atrox, B. insularis, B. leucurus, B. brazili, B. moojeni, $B$. neuwiedi, and $B$. pauloensis), three Crotalus ( $C$. durissus terrificus, $C$. durissus cascavella, and $C$. atrox), and two toxins (gyroxin, crotamine) showed highly significant antibacterial activity, with a bacterial growth inhibition level of $100 \%$, similarly to the positive control chloramphenicol. PLA2-CB and B. jararacussu venom also showed significant activity, with 52 and $38 \%$ of bacterial growth inhibition, respectively, while other venoms such as those of Lachesis muta and B. urutu, and BthTX-I, did not differ from the negative control used in the tests. Thus, ten venoms and two toxins were selected for the $\mathrm{MIC}$ and $\mathrm{LC}_{50}$ analyses.

The inhibition of $R$. solanacearum growth showed a dose-dependent response pattern, and, even at lower doses, it was possible to observe an inhibitory activity in a range of at least $20 \%$ (Figure 3 ). The effect of the selected venoms and toxins on $R$. solanacearum were

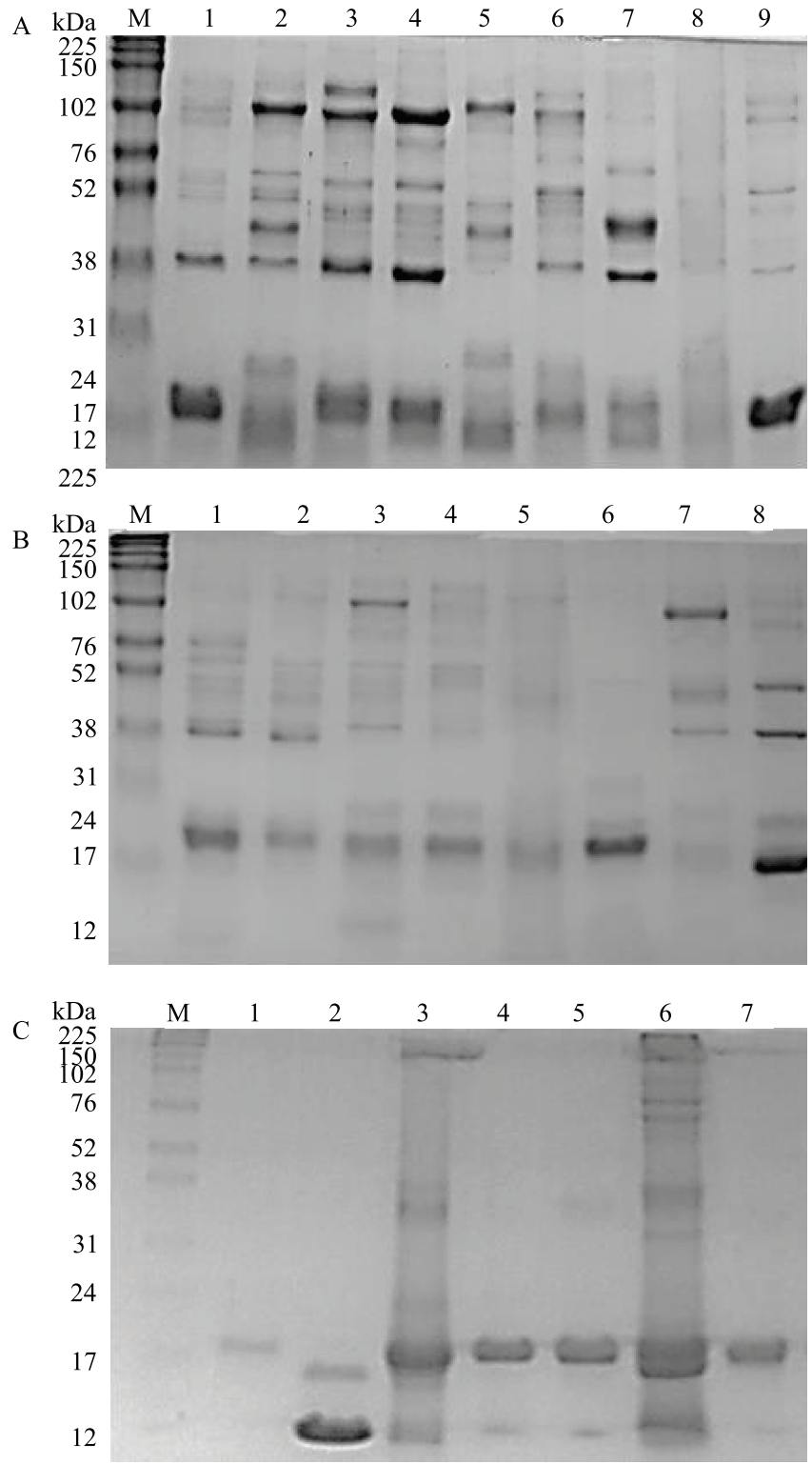

Figure 1. SDS-PAGE of protein pattern of snake venoms (A and B) and toxins (C). A: M - molecular weight marker (MW); 1, Bothrops jararacussu; 2, B. jararaca; 3, B. diporus; 4, B. marajoensis; 5, B. alternatus; 6, B. urutu; 7, B. atrox; 8 , B. insularis; and 9, B. leucurus. B: M-MW; 1 , B. brazili; 2, B. moojeni; 3, B. neuwiedi; 4, B. pauloensis; 5, C. durissus terrificus; $6, C$. durissus cascavella; $7, C$. atrox; and 8, Lachesis muta. $\mathrm{C}: \mathrm{M}-\mathrm{MW}$; 1 gyroxin; 2, crotamine; 3, crotapotin; 4, crotoxin; 5, BthTX-I; 6, convulxin; and 7, PLA2-CB. Protein concentration was adjusted to $5 \mu \mathrm{g}$ in a final volume of $20 \mu \mathrm{L}$ for each sample. Samples were run on $15 \%$ gels and stained using $0.5 \%$ Coomassie brilliant blue solution. Estimated molecular weight was determined using MW markers. 
expressed through the calculated values of $\mathrm{LC}_{50}$ and the MIC (Table 3). While $\mathrm{LC}_{50}$ values ranged from 28.50 $\mu \mathrm{g} \mathrm{mL} \mathrm{m}^{-1}$ to $4.39 \mathrm{mg} \mathrm{mL}^{-1}$, MIC values ranged from 0.4 to $271.5 \mu \mathrm{g} \mathrm{mL}^{-1}$.

Antibacterial activity was also described for L-amino acid oxidase (LAAO) purified from C. durissus

Table 2. Analysis of variance of antibacterial activity assays of snake venoms and toxins against Ralstonia solanacearum.

\begin{tabular}{lrcc}
\hline $\begin{array}{l}\text { Source of } \\
\text { variance }\end{array}$ & DF & F & p-value \\
\hline Treatment & 25 & $331.91^{* *}$ & 0.00 \\
\hline Venoms/toxins (VT) & 23 & $327.42^{* *}$ & 0.00 \\
Control (C) & 1 & $754.66^{* *}$ & 0.00 \\
VT x C & 1 & $12.25^{* *}$ & 0.00 \\
\hline Error & 52 & - & \\
\hline Total & 77 & - & \\
\hline Mean & 38.16 & - & \\
CV $(\%)$ & 9.53 & - & \\
\hline
\end{tabular}

$\mathrm{CV}$, coefficient of variation; DF, degrees of freedom; F, analysis of variance test. ${ }^{* *}$ Significant at $1 \%$ probability. cascavella venom, against Xanthomonas axonopodis pv. passiflorae and Staphylococcus mutans, with $\mathrm{LC}_{50}$ of $35 \mu \mathrm{g} \mathrm{mL}^{-1}$ and $12.3 \mu \mathrm{g} \mathrm{mL}^{-1}$, respectively (Toyama et al., 2006). Other studies indicated that the venoms of C. adamanteus, Daboia russelli russelli, A. halis, Pseudechis australis, B. candidus, and P. guttata showed activity against different pathogenic bacteria, with higher activity against $S$. aureus, and MIC values ranged from 20.0-40.0 $\mu \mathrm{g} \mathrm{mL}^{-1}$ (Samy et al., 2007). Moreover, a $\mathrm{PLA}_{2}$ purified from Vipera russellii venom and the VRV-PL-VII-A fraction obtained from D. pulchella russelli venom showed activity against Escherichia coli, Klebsiella pneumoniae, and Salmonella paratyphi (Sudharshan \& Dhananjaya, 2015). Furthermore, BmLec, a protein purified from the venom of Bothrops moojeni, was able to reduce $15 \%$ of the bacterial growth of $X$. axonopodis pv. passiflorae (Barbosa et al., 2010). A venom fraction of $C$. durissus terrificus showed antibacterial activity against the phytopathogenic pathogens $X$. axonopodis pv passiflorae and Clavibacter michiganensis michiganensis (Rádis-Batista et al., 2005).

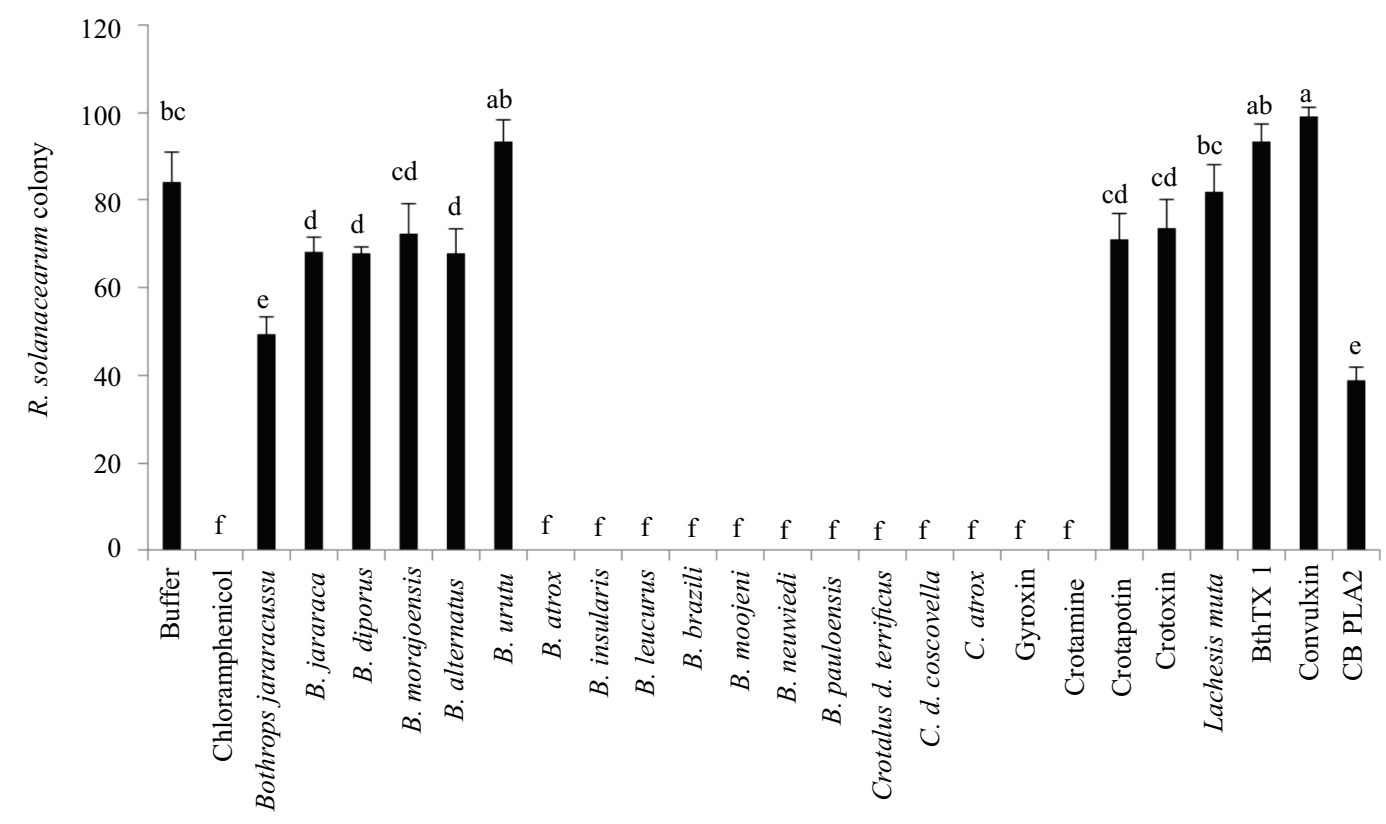

Treatments

Figure 2. Ralstonia solanacearum colony averages when challenged with snake venoms and toxins. Chloramphenicol and phosphate-buffered saline (PBS) were used as positive and negative controls, respectively. Means of columns followed by equal letters do not differ by the Tukey's test, at $1 \%$ probability. 
In the present study, most of the antibacterial activity was found in venoms of the Bothrops genus (Figures 2 A, 2 B, 3 A, and 3 B). This activity may be explained by the high variability in the composition of venoms, which can be responsible for a local damage that possibly deactivates the bacterial wall and initiates an irrecoverable process, hindering the genetic synthesis that allow of bacteria replication, which justifies the minimal or none bacterial growth (Gutiérrez et al., 2017; Malange et al., 2019).

The present work provides new information on plant bacterial study, presenting substances with potential uses in biotechnological processes to improve pathogen control. Therefore, ten crude venoms and two purified toxins against $R$. solanacearum were herein selected based on their antibacterial activity. Further studies
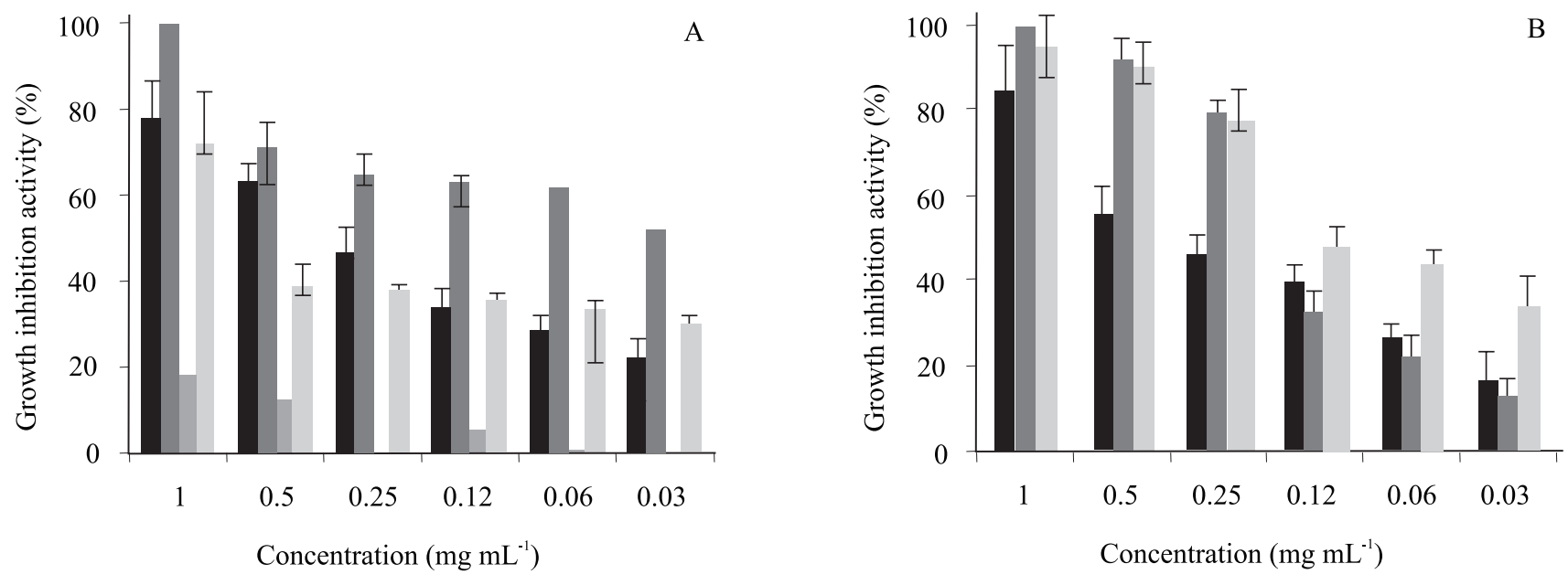

B. atrox B. insularis $\square$ B. leucurus $\square$ B. brazili

B. moojeni $\square$ B. neuwiedi $\square$ B. pauloensis
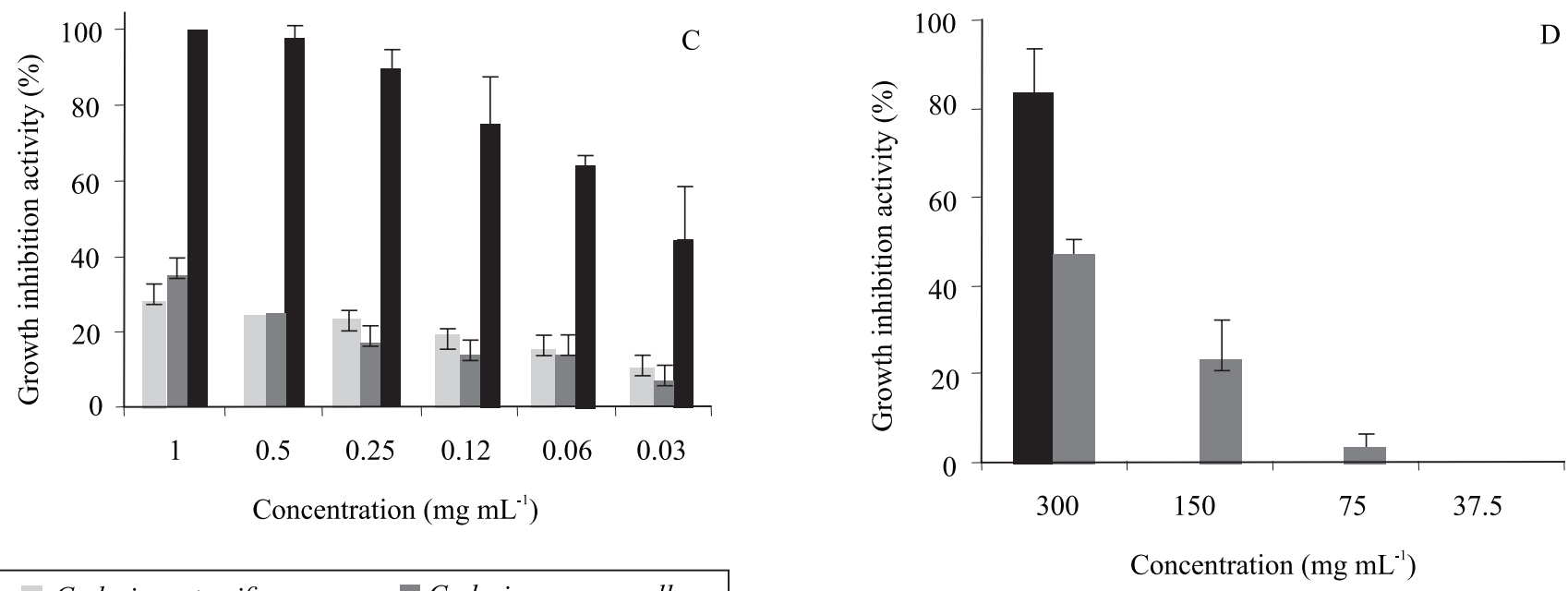

C. durissus terrificus $\square$ C. durissus cascavella
C. atrox

Gyroxin Crotamine

Figure 3. Growth inhibition activity of snake venoms and toxins against Ralstonia solanacearum. Concentrations from $1.0-0.03 \mathrm{mg} \mathrm{mL}^{-1}$ and 300-37.5 $\mu \mathrm{g} \mathrm{mL}^{-1}$ of venoms and toxins, respectively, were used. A and B, venoms of Bothrops spp.; $\mathrm{C}$, venoms of Crotalus spp.; D, purified toxins. Inhibition activity was calculated observing the negative control (PBS). 
Table 3. Lethal concentration $\left(\mathrm{LC}_{50}\right)$ and minimum inhibitory concentration (MIC) of snake venoms and toxins against Ralstonia solanacearum

\begin{tabular}{lcr}
\hline Treatment & $\mathrm{LC}_{50}\left(\mathrm{mg} \mathrm{mL}^{-1}\right)$ & $\mathrm{MIC}\left(\mu \mathrm{g} \mathrm{mL}^{-1}\right)$ \\
\hline Bothrops atrox & 0.25 & 1.40 \\
B. insularis & 0.02 & 5.80 \\
B. leucurus & 1.14 & 271.50 \\
B. brazili & 0.83 & 0.40 \\
B. moojeni & 0.24 & 2.30 \\
B. neuwiedi & 0.13 & 13.30 \\
B. pauloensis & 0.08 & 1.90 \\
Crotalus atrox & 0.04 & 1.80 \\
C. durissus terrificus & 1.14 & 214.50 \\
C. durissus cascavella & 4.39 & 1.80 \\
Gyroxin & 0.30 & 12.60 \\
Crotamine & 0.30 & 46.60 \\
\hline
\end{tabular}

should clarify the mechanisms involved in this activity and future applications.

\section{Conclusions}

1. Ten crude snake venoms show antibacterial activity against Ralstonia solanacearum - seven from Bothrops spp. and three from Crotalus spp. are able to inhibit more than $90 \%$ of the bacteria growth in vitro, with special attention to Bothrops insularis and Crotalus atrox.

2. Two snake toxins - gyroxin and crotamine -, isolated from Crotalus durissus terrificus, are able to inhibit the in vitro growth of $R$. solanacearum.

\section{Acknowledgments}

To Conselho Nacional de Desenvolvimento Científico e Tecnológico (CNPq, through CFF - grant no. 485047/2013-6), to Financiadora de Estudos e Projetos (Finep), to Fundação Rondônia de Amparo ao Desenvolvimento das Ações Científicas e Tecnológicas e de Pesquisa do Estado de Rondônia (Fapero), to Coordenação de Aperfeiçoamento de Pessoal de Nível Superior (Capes, finance code 001), for financial support and for postgraduate fellowships to Rita de Cássia Alves, Tamiris Chaves Freire, and Aline Souza Fonseca ; to Domingos Sávio G. Silva and Antônio M. Marques, for technical support; to Amy Nicole Grabner for the English review of the manuscript; and to Program for Technological Development in Tools for Health-PDTIS-
Fiocruz, for the permission to use of its facilities. The funders had no role in study design, data collection and analyses, decision to publish, or preparation of the manuscript.

\section{References}

ALMEIDA, J.R.; RESENDE, L.M.; WATANABE, R.K.; CORASSOLA, V.C.; HUANCAHUIRE-VEJA, S.; CALDEIRA, C.A. da S.; COUTINHO-NETO, A.; SOARES, A.M.; VALE, N.; GOMES, P.A. de C.; MARANGONI, S.; CALDERON, L. de A.; SILVA, S.L. da. Snake venom peptides and low mass proteins: molecular tools and therapeutic agents. Current Medicinal Chemistry, v.24, p.3254-3282, 2017. DOI: https://doi.org/10.2174/ 0929867323666161028155611.

ANDRIÃO-ESCARSO, S.H.; SOARES, A.M.; RODRIGUES, V.M.; ANGULO, Y.; DÍAZ, C.; LOMONTE, B.; GUTIÉRREZ, J.M.; GIGLIO, J.R. Myotoxic phospholipases $\mathrm{A}_{2}$ in Bothrops snake venoms: effect of chemical modifications on the enzymatic and pharmacological properties of bothropstoxins from Bothrops jararacussu. Biochimie, v.82, p.755-763, 2000. DOI: https://doi.org/10.1016/S0300-9084(00)01150-0.

BAPTISTA, M.J.; REIS JUNIOR, F.B. dos; XAVIER, G.R.; ALCÂNTARA, C. de; OLIVEIRA, A.R. de; SOUZA, R.B.; LOPES, C.A. Eficiência da solarização e biofumigação do solo no controle da murcha-bacteriana do tomateiro no campo. Pesquisa Agropecuária Brasileira, v.42, p.933-938, 2007. DOI: https://doi.org/10.1590/s0100-204x2007000700004.

BARBOSA, P.S.F.; MARTINS, A.M.C.; TOYAMA, M.H.; JOAZEIRO, P.P.; BERIAM, L.O.S.; FONTELES, M.C.; MONTEIRO, H.S.A. Purification and biological effects of a C-type lectin isolated from Bothrops moojeni. The Journal of Venomous Animals and Toxins including Tropical Diseases, v.16, p.493504, 2010. DOI: https://doi.org/10.1590/S1678-91992010000300016.

BERCOVICI, D.; CHUDZINISKI, A.M.; DIAS, W. de O.; ESTEVES, M.I.; HIRACHI, E.; OISHI, N.Y.; PICARELLI, Z.P.; ROCHA, M.C. da; UEDA, C.M.P.M.; YAMANOUYE, N.; RAW, I. A systematic fractionation of Crotalus durissus terrificus venom. Memórias do Instituto Butantan, v.49, p.69-78, 1987.

BOLDRINI-FRANÇA, J.; COLOGNA, C.T.; PUCCA, M.B.; BORDON, K. de C.F.; AMORIM, F.G.; ANJOLETTE, F.A.P.; CORDEIRO, F.A.; WIEZEL, G.A.; CERNI, F.A.; PINHEIROJUNIOR, E.L.; SHIBAO, P.Y.T.; FERREIRA, I.G.; OLIVEIRA, I.S. de; CARDOSO, I.A.; ARANTES, E.C. Minor snake venom proteins: structure, function and potential applications. Biochimica et Biophysica Acta, v.1861, p.824-838, 2017. DOI: https://doi. org/10.1016/j.bbagen.2016.12.022.

CESPEDES, C.L.; ALARCON, J.; AQUEVEQUE, P.M.; LOBO, T.; BECERRA, J.; BALBONTIN, C.; AVILA, J.G.; KUBO, I.; SEIGLER, D.S. New environmentally-friendly antimicrobials and biocides from Andean and Mexican biodiversity. Environmental Research, v.142, p.549-562, 2015. DOI: https://doi.org/10.1016/j. envres.2015.08.004. 
CRUZ, C.D. Genes software - extended and integrated with the R, Matlab and Selegen. Acta Scientiarum. Agronomy, v.38, p.547552, 2016. DOI: https://doi.org/10.4025/actasciagron.v38i4.32629.

DALSING, B.L.; TRUCHON, A.N.; GONZALEZ-ORTA, E.T.; MILLING, A.S.; ALLEN, C. Ralstonia solanacearum uses inorganic nitrogen metabolism for virulence, ATP production, and detoxification in the oxygen-limited host xylem environment. mBio, v.6, e02471-14, 2015. DOI: https://doi.org/10.1128/mBio.02471-14.

DATTA, A.; GHOSH, A.; AIROLDI, C.; SPERANDEO, P.; MROUE, K.H.; JIMÉNEZ-BARBERO, J.; KUNDU, P.; RAMAMOORTHY, A.; BHUNIA, A. Antimicrobial peptides: insights into membrane permeabilization, lipopolysaccharide fragmentation and application in plant disease control. Scientific Reports, v.5, e11951, 2015. DOI: https://doi.org/10.1038/srep11951.

GUTIÉRREZ, J.M.; CALVETE, J.J.; HABIBI, A.G.; HARRISON, R.A.; WILLIAMS, D.J.; WARREL, D.A. Snakebite envenoming. Nature Reviews Disease Primers, v.3, art.17063, 2017. DOI: https://doi.org/10.1038/nrdp.2017.63.

KADO, C.I.; HESKETT, M.G. Selective media for isolation of Agrobacterium, Corynebacterium, Erwinia, Pseudomonas and Xanthomonas. Phytopathology, v.60, p.969-976, 1970. DOI: https:// doi.org/10.1094/Phyto-60-969.

KASS, E.H. Asymptomatic infections of the urinary tract. Transactions of the Association of American Physicians, v.69, p.56-64, 1956.

KWAK, A.M.; MIN, K.J.; LEE, S.Y.; KANG, H.W. Water extract from spent mushroom substrate of Hericium erinaceus suppresses bacterial wilt disease of tomato. Mycobiology, v.43, p.311-318, 2015. DOI: https://doi.org/10.5941/MYCO.2015.43.3.311.

LAEMMLI, U.K. Cleavage of structural proteins during the assembly of the head of bacteriophage T4. Nature, v.227, p.680685, 1970. DOI: https://doi.org/10.1038/227680a0.

MALANGE, K.F.; DOS SANTOS, G.G. dos; KATO, N.N.; TOFFOLI-KADRI, M.C.; CAROLLO, C.A.; SILVA, D.B.; PORTUGAL, L.C.; ALVES, F.M.; RITA, P.H.S.; PARADA, C.A.; RONDON, E.S. Tabebuia aurea decreases hyperalgesia and neuronal injury induced by snake venom. Journal of Ethnopharmacology, v.233, p.131-140, 2019. DOI: https://doi.org/10.1016/j.jep.2018.12.037.

MOHAMED, A.A.; BEHIRY, S.I.; YOUNES, H.A.; ASHMAWY, N.A.;SALEM,M.Z.M.; MÁRQUEZ-MOLINA, O.;BARBABOSAPILEGO, A. Antibacterial activity of three essential oils and some monoterpenes against Ralstonia solanacearum phylotype II isolated from potato. Microbial Pathogenesis, v.135, art. 103604, 2019. DOI: https://doi.org/10.1016/j.micpath.2019.103604.

NUNES, E. dos S.; SOUZA, M.A.A. de; VAZ, A.F. de M.; SANTANA, G.M. de S.; GOMES, F.S.; COELHO, L.C.B.B.; PAIVA, P.M.G.; SILVA, R.M.L. da; SILVA-LUCCA, R.A.; OLIVA, M.L.V.; GUARNIERI, M.C.; CORREIA, M.T. dos S. Purification of a lectin with antibacterial activity from Bothrops leucurus snake venom. Comparative Biochemistry and Physiology, Part B, v.159, p.57-63, 2011. DOI: https://doi.org/10.1016/j.cbpb.2011.02.001.

PAIVA, R. de M.A.; FIGUEIREDO, R. de F.; ANTONUCCI, G.A.; PAIVA, H.H.; BIANCHI, M. de L.P.; RODRIGUES,
K.C.; LUCARINI, R.; CAETANO, R.C.; PIETRO, R.C.L.R.; MARTINS, C.H.G.; ALBUQUERQUE, S. de; SAMPAIO, S.V. Cell cycle arrest evidence, parasiticidal and bactericidal properties induced by L-amino acid oxidase from Bothrops atrox snake venom. Biochimie, v.93, p.941-947, 2011. DOI: https://doi.org/10.1016/j.biochi.2011.01.009.

PEETERS, N.; GUIDOT, A.; VAILLEAU, F.; VALLS, M. Ralstonia solanacearum, a widespread bacterial plant pathogen in the postgenomic era. Molecular Plant Pathology, v.14, p.651-662, 2013. DOI: https://doi.org/10.1111/mpp.12038.

RÁDIS-BAPTISTA, G.; MORENO, F.B.M.B.; NOGUEIRA, L.L.; MARTINS, A.M.C.; TOYAMA, D.O.; TOYAMA, M.H.; AZEVEDO JR, W.F.; CAVADA, B.S.; YAMANE, T. Crotacetin, a novel snake venom c-type lectin, is homolog of convulxin. Journal of Venomous Animals and Toxins including Tropical Diseases, v.11, p.557-578, 2005. DOI: https://doi.org/10.1590/S167891992005000400013.

RESENDE, L.M.; ALMEIDA, J.R.; SCHEZARO-RAMOS, R.; COLLAÇO, R.C.O.; SIMIONI, L.R.; RAMÍREZ, D.; GONZÁLEZ, W.; SOARES, A.M.; CALDERON, L.A.; MARANGONI, S.; SILVA, S.L. da. Exploring and understanding the functional role, and biochemical and structural characteristics of an acidic phospholipase A2, AplTx-I, purified from Agkistrodon piscivorus leucostoma snake venom. Toxicon, v.127, p.22-36, 2017. DOI: https://doi.org/10.1016/j.toxicon.2017.01.002.

RODRIGUES, B.; MORAIS, T.P.; ZAINI, P.A.; CAMPOS, C.S.; ALMEIDA-SOUZA, H.O.; DANDEKAR, A.M.; NASCIMENTO, R.; GOULART, L.R. Antimicrobial activity of Epsilon-Poly-Llysine against phytopathogenic bacteria. Scientific Reports, v.10, art. 11324, 2020. DOI: https://doi.org/10.1038/s41598-020-68262-1.

SAMY, R.P.; GOPALAKRISHNAKONE, P.; THWIN, M.M.; CHOW, T.K.V.; BOW, H.; YAP, E.H.; THONG, T.W.J. Antibacterial activity of snake, scorpion and bee venoms: a comparison with purified venom phospholipase A2 enzymes. Journal of Applied Microbiology, v.102, p.650-659, 2007. DOI: https://doi.org/10.1111/ j.1365-2672.2006.03161.x.

SAMY, R.P.; SETHI, G.; LIM, L.H.K. A brief update on potential molecular mechanisms underlying antimicrobial and wound-healing potency of snake venom molecules. Biochemical Pharmacology, v.115, p.1-9, 2016. DOI: https://doi.org/10.1016/j. bcp.2016.03.006.

SMITH, P.K.; KROHN, R.I.; HERMANSON, G.T.; MALLIA, A.K.; GARTNER, F.H.; PROVENZANO, M.D.; FUJIMOTO, E.K.; GOEKE, N.M.; OLSON, B.J.; KLENK, D.C. Measurement of protein using bicinchoninic acid. Analytical Biochemistry, v.150, p.76-85, 1985. DOI: https://doi.org/10.1016/0003-2697(85)90442-7.

SUDHARSHAN, S.; DHANANJAYA, B.L. Antibacterial potential of a basic phospholipase A2 (VRV-PL-VIIIa) from Daboia russelii pulchella (Russell's viper) venom. Journal of Venomous Animals and Toxins including Tropical Diseases, v.21, art.17, 2015. DOI: https://doi.org/10.1186/s40409-015-0014-y.

TASHIMA, A.K.; ZELANIS, A.; KITANO, E.S.; IANZER, D.; MELO, R.L.; RIOLI, V.; SANT'ANNA, S.S.; SCHENBERG, A.C.G.; CAMARGO, A.C.M.; SERRANO, S.M.T. Peptidomics of three Bothrops snake venoms: insights into the molecular

Pesq. agropec. bras., Brasília, v.55, e01756, 2020

DOI: 10.1590/S1678-3921.pab2020.v55.01756 
diversification of proteomes and peptidomes. Molecular \& Cellular Proteomics, v.11, p.1245-1262, 2012. DOI: https://doi.org/10.1074/mcp.M112.019331.

TORRES, A.F.C.; DANTAS, R.T.; TOYAMA, M.H.; DIZ FILHO, E.; ZARA. F.J.; QUEIROZ, M.G.R. de; NOGUEIRA, N.A.P.; OLIVEIRA, M.R. de; TOYAMA, D. de O.; MONTEIRO, H.S.A.; MARTINS, A.M.C. Antibacterial and antiparasitic effects of Bothrops marajoensis venom and its fractions: Phospholipase A2 and L-amino acid oxidase. Toxicon, v.55, p.795-804, 2010. DOI: https://doi.org/10.1016/j.toxicon.2009.11.013.

TOYAMA, M.H.; TOYAMA, D. de O.; PASSERO, L.F.D.; LAURENTI, M.D.; CORBETT, C.E.; TOMOKANE, T.Y.;
FONSECA, F.V.; ANTUNES, E.; JOAZEIRO, P.P.; BERIAM, L.O.S.; MARTINS, M.A.C.; MONTEIRO, H.S.A.; FONTELES, M.C. Isolation of a new L-amino acid oxidase from Crotalus durissus cascavella venom. Toxicon, v.47, p.47-57, 2006. DOI: https://doi.org/10.1016/j.toxicon.2005.09.008.

YADETA, K.A.; THOMMA, B.P.H.J. The xylem as battleground for plant hosts and vascular wilt pathogens. Frontiers in Plant Science, v.4, art.97, 2013. DOI: https://doi.org/10.3389/fpls.2013.00097.

YULIAR; NION, Y.A.; TOYOTA, K. Recent trends in control methods for bacterial wilt diseases caused by Ralstonia solanacearum. Microbes and Environments, v.30, p.1-11, 2015. DOI: https://doi.org/10.1264/jsme2.ME14144. 